\title{
DIFERENÇA COMO ABERTURA DE MUNDOS POSSÍVEIS: APRENDIZAGEM E ALTERIDADE
}

\author{
Cíntia Vieira da Silva* \\ Kátia Maria Kasper **
}

\begin{abstract}
RESUMO
Quais as relações possíveis entre aprendizagem e diferença? Circula entre nós, por exemplo, a ideia - de resto, muito pertinente - de que é preciso aprender a conviver com as diferenças. Este artigo desloca esta discussão, colocando-se em uma perspectiva segundo a qual só se aprende por meio do contato, nem sempre apaziguado, com a diferença. Aprender envolve ser levado a diferir de si através do contato com o outro, tendo muito pouco (ou nada) a ver com a imitação de um modelo ou a aplicação de um método. Procuramos expor o conceito de 'outrem', elaborado por Deleuze nos textos "Causas e razões das ilhas desertas" e "Michel Tournier e o mundo sem outrem”. Percorremos também a recriação da história de Robinson Crusoé, Sexta-feira ou os limbos do pacífico, romance que é um dos intercessores na criação do conceito deleuziano de diferença.
\end{abstract}

Palavras-chave: Aprendizagem. Alteridade. Deleuze. Diferença. Outrem.

\section{RESUMÉ}

Quels sont les rapports possibles entre apprentissage et différence ? L'ídée - d'ailleurs tout à fait pertinente - qu'il faut apprendre à vivre avec les différences - circule parmi nous. Cet article déplace la discussion en se plaçant dans une perspective selon laquelle on n'apprend qu'au moyen du contact, pas toujours paisible, avec la différence. Apprendre amène à différer de soi au travers du contact avec l'autre, et n'a que peu (ou

\footnotetext{
* Doutora em Filosofia pela Universidade Estadual de Campinas (Unicamp). Professora Adjunta no Departamento de Filosofia e no Mestrado em Estética e Filosofia da Arte da Universidade Federal de Ouro Preto (UFOP).E-mail: cintiavs@gmail.com

** Doutora em Educação pela Universidade Estadual de Campinas (Unicamp). Professora do Setor de Educação da Universidade Federal do Paraná (UFPR). E-mail: katiakasper@, uol.com.br
} 
rien) à voir avec l'imitation d'un modèle ou l'application d'une méthode. Nous cherchons à exposer le concept d' «autrui» élaboré par Deleuze dans les textes «Causes et raisons des îles désertes» et «Michel Tournier et le monde sans autrui». Nous parcourons également la recréation de l'histoire de Robinson Crusoé, Vendredi ou les limbes du Pacifique, roman qui est l'un des intercesseurs de la création du concept deleuzien de différence.

Mots clé: Apprentissage. Altérité. Deleuze. Différence. Autrui.

Este artigo propõe um percurso por alguns textos de Gilles Deleuze que tratam do conceito de 'outrem', visando extrair elementos para elaborar uma concepção a mais ampliada possível do que seria aprender. Uma tal concepção interessa aos discursos teóricos em torno da educação, assim como, de maneira mais geral, à construção de uma perspectiva filosófica a respeito do pensamento como processo de criação problematizante. Tal perspectiva distancia-se daquelas que procuram ver o pensamento como atividade de adequação entre representações e percepções, envolvendo, portanto, uma renovação do conceito de aprendizagem. Nesse sentido, o processo de ensino-aprendizagem não pode ser mais visto como conjunto de procedimentos conduzindo a um resultado previsto de antemão, em espaço e tempo determinados. Aprender, nesta perspectiva proposta por Deleuze, torna-se aventura imprevisível porque deflagrada pelo contato com diferenças, com o que desestabiliza certezas, com o que provoca problemas novos. Tendo em vista tal perspectiva, iniciemos o trajeto pelos textos.

Ao final de Lógica do sentido, Deleuze coloca cinco textos em apêndice, distribuídos em duas partes: Simulacro e filosofia antiga e Fantasma e literatura moderna. Simulacro e fantasma constituem, em Lógica do sentido, duas figuras assumidas pela diferença ou, melhor dizendo, dois recursos conceituais que auxiliam na elaboração de uma filosofia da diferença. Ambas as figuras se delineiam numa dimensão de superfície, em contraste tanto com relação à profundidade dos corpos que se chocam e interpenetram, quanto com a altura, dimensão em que Deleuze coloca as ideias de tipo platônico. O livro parte da obra de Lewis Carrol e da teoria dos incorporais dos estoicos para compor uma teoria da produção do sentido em duas frentes: a partir das proposições e a partir dos corpos, ou seja, remontando à instauração da linguagem como superfície 
que se desprende do corpo. Nos dois encaminhamentos, o sentido surge como acontecimento que não se confunde com os estados de coisa a que se refere, nem com as ações e paixões dos corpos.

Ora, o fantasma é definido justamente como acontecimento, como efeito das ações e paixões, efetuado nos estados de coisa. É o efeito de superfície ideal que corresponde ao simulacro como elemento diferencial que surge da profundidade corporal, formando um sistema simulacrofantasma que funciona por diferença e por divergência das séries. Tal sistema opera uma verdadeira reversão do platonismo. $\mathrm{O}$ método de divisão platônica visava distinguir o modelo e as cópias, mas, sobretudo, a cópia do simulacro. No fundo, é um método de seleção dos pretendentes: sobreviverá à prova o elemento que corresponder ao critério de semelhança com relação ao modelo, ou seja, a Ideia. Assim, a seleção acaba por conjurar o simulacro, cópia baseada na dissimilitude e que só obtém a semelhança como efeito exterior, como impressão de um observador localizado em determinado ponto de vista. No jogo entre os diversos pontos de vista, produz-se uma semelhança como efeito de seres divergentes. O fantasma é precisamente a imagem resultante dessa subida dos simulacros à superfície, que a divisão platônica buscava impedir, ao basear o critério de seleção na semelhança. Deleuze aponta a arte como lugar privilegiado de produção dessas séries divergentes e descentradas, especialmente a literatura, com as experimentações em torno de narrativas abertas que proliferam pontos de vista que só podem ser unificados numa espécie de caos, como no Finnegan's wake de James Joyce.

Mas o texto de que vamos tratar aqui convoca um outro escritor, Michel Tournier, com a sua recriação da história de Robinson Crusoé, chamada Sexta-feira ou os limbos do pacífico. O texto se intitula Michel Tournier e o mundo sem outrem e se encontra no segundo grupo de apêndices que mencionamos, Fantasma e literatura moderna. Já de início poderíamos atribuir o pertencimento do texto de Tournier ao sistema simulacro-fantasma à relação que entretém com o Robinson Crusoé de Defoe. Com efeito, o livro de Tournier não é apenas uma versão da história contada anteriormente por Defoe, versão que partiria de um ponto de vista diferente, o ponto de vista de Sexta-feira, como poderíamos ser levados a pensar em função de seu título. O livro é ele próprio uma espécie de 
desvio, de linha divergente, em relação ao texto anterior, procedimento característico do mundo dos simulacros. Assim, não é apenas o ponto de vista da narrativa que muda. Tournier nos coloca diante de um Robinson muito diferente do anterior. A diferença é a tal ponto assegurada que nem é preciso alterar a forma da narração para garanti-la. Num texto como no outro, é Robinson Crusoé quem nos conta sua história. Em ambos os casos, portanto, o narrador é Robinson Crusoé, mas não é um mesmo Robinson Crusoé num e noutro romance, assim como não é uma mesma história que nos é contada.

O Robinson Crusoé de Defoe se construía em torno de uma investigação a respeito das origens da ordem econômica, das atividades produtivas e conquistas capazes de engendrar esta ordem. Mas as condições desta investigação constrangem os resultados, fazem com que o mundo recriado na ilha seja uma reprodução do mundo do qual Robinson foi apartado ao naufragar. Prova disso é o fato, por exemplo, de Robinson produzir a partir dos despojos do naufrágio. Os fins que este primeiro Robinson se coloca acabam por espelhar a origem, mas não a origem do recomeço e sim a sociedade original da qual partiu. Como se Defoe não tivesse levado às últimas consequências, a pergunta que movia seu romance com ares de inquérito: "o que pode ocorrer a um homem só, sem Outrem, em uma ilha deserta?” (DELEUZE, 1998, p. 313).

O livro de Tournier seria então, para Deleuze, a extração de todas as consequências dessa pergunta, mas em condições tais que ela dá lugar verdadeiramente a um experimento em torno da ausência de outrem. Esta experimentação permite vislumbrar não apenas o que acontece num mundo sem outrem, mas também, como consequência, ensina a respeito do papel de outrem. Que condições são essas que permitem a realização efetiva do experimento? Em primeiro lugar, trata-se de uma maneira diferente de colocar o problema que consiste em abandonar a pergunta pelas origens de uma ordem produtiva. Ao deixar de lado esta preocupação genética, Tournier torna possível o surgimento de um desfecho e de um "alvo final" (DELEUZE, 1998, p. 313) que não são simplesmente o espelhamento e a retomada do começo. A história de Robinson deixa de ser a da tentativa de reconstruir uma microssociedade a partir das condições de um naufrágio numa ilha deserta para se tornar a história da erosão de todas as estruturas 
sociais internalizadas num homem. O que o livro de Tournier nos conta é um processo de desumanização. O homem sozinho numa ilha deserta vai sendo tomado pelos elementos, terra, água, ar até se tornar ele mesmo elementar. Abandona, assim, uma subjetividade previamente moldada pela forma-homem (civilizado, branco, do sexo masculino, europeu, e assim por diante), engajando-se em modos de subjetivação imprevistos e diferenciais.

Vale a pena nos determos um momento em alguns aspectos da narrativa do livro comentado por Deleuze. Defoe (escritor inglês do século XVIII) foi o criador dessa narrativa de Robinson, sobrevivente de um naufrágio ocorrido no século XVII. Baseado numa história real de um náufrago que é encontrado em uma ilha deserta, à $650 \mathrm{~km}$ da costa do Chile. Um escritor francês contemporâneo, Michel Tournier, escreve uma história de outro Robinson Crusoé: Sexta-feira ou os limbos do Pacífico.

Em decorrência de uma tempestade, o navio no qual viajava Robinson naufraga numa ilha deserta. Toda a tripulação morre, sendo ele o único sobrevivente - ele e um cachorro. Sua primeira reação foi pensar que seria rapidamente resgatado. Tanto que oscilou muito até recolher os restos do naufrágio, para que não fossem levados por um novo acidente náutico. Passa um tempo meio atordoado, alimentando-se de frutas que colhia das plantas, sem esforço, ovos de tartaruga, mariscos. Coisas que estavam ao seu alcance imediato.

A ideia é sair da ilha. Ele a nega enquanto lugar. Seria totalmente provisória. Passado esse primeiro estado, sentindo que não há indícios de resgate imediato ele começa, então, a criar ele mesmo o seu modo de escapar da ilha. O nome do barco é Evasão.

Nesse segundo movimento, Robinson embriaga-se pelo trabalho. Retira materiais do outro barco e constrói o Evasão. Escolhe um lugar bem alto para construir o barco e, ao mesmo tempo, vigiar o mar, de onde poderia surgir sua salvação. Trabalho febril, compulsivo, de construção do barco. O barco ficará para sempre na sua carne, diz ele, pensando nas marcas deixadas em seu corpo com o trabalho de construção de Evasão. Quando a parte principal do barco fica pronta, o casco, que deve pesar mais de quinhentos quilos, ele percebe que não conseguirá levar o barco até o mar, a costa. Está muito longe e é muito pesado. Robinson adora calcular e fazendo os cálculos, conclui que mesmo passando o resto de sua vida 
cavando um canal para deslizá-lo, não conseguiria. Renuncia.

Depois disso, Robinson entra num outro estado, de ficar mergulhado na lama, como os javalis, os porcos selvagens que moravam na ilha. Deixa seu corpo passivo, abandonado, misturado com a lama. Em uma espécie de regressão, pensa no passado. Como se estivesse se retirando do mundo. Como um caracol recolhido em si mesmo. Até que sai da lama e começa um outro processo de civilizar, domesticar a ilha.

Não deixa de virar as costas para ela, enquanto ilha, pois quer transformá-la em rudimentos da Europa civilizada. Passa a domesticar cabras, a plantar, a construir, a elaborar leis. Para medir o tempo constrói um calendário e um relógio de água. Constrói até uma igreja e um Palácio da justiça. Auto elege-se governador. Quer construir na ilha uma civilização nos moldes da que deixara.

Em vários momentos, Robinson tem a intuição de uma outra ilha, mas tal intuição é sempre soterrada pela rotina que ele estabeleceu. Tournier mostra, neste ponto, a rotina e os hábitos operando para impedir mudanças, impedir o novo. A tentativa desesperada de Robinson em transformar a ilha desconhecida em algo familiar impede que ele sequer veja a ilha em suas diferenças singulares, como lugar não meramente deserto ou vazio, mas povoado de elementos perturbadores, desestabilizadores, inclassificáveis segundo os moldes da civilização a que Robinson se habituara antes do naufrágio.

Nesta fase, Robinson reencontra um cachorro que sobrevivera ao naufrágio e que o evitara até então. Quando o cachorro fugiu dele, logo no início de sua estada na ilha, Robinson pensara que o cachorro reencontrara seu estado selvagem (sua antiga animalidade). Quando Ten volta, Robinson percebe que ele fugira porque Robinson encontrara um estado selvagem. Que o animal fugiu de medo do bicho que ele, Robinson, se tornara. Como se o cão também temesse se relacionar com um elemento estranho aos seus hábitos, diferente do costumeiro.

A ilha era utilizada por nativos da região, como um local de realização de sacrifício humano. Robinson observara várias vezes os nativos chegarem na praia e sacrificarem alguém. Durante o processo de tentativa de civilização da ilha, surge um nativo da região (que seria sacrificado e Robinson, por acaso, salva), que é incorporado por Robinson 
ao esquema de administração da ilha criado por ele, no único lugar onde cabia: como escravo.

Robinson precisa nomear o nativo, mas percebendo-o como um ser fronteiriço entre a humanidade e a animalidade, não consegue decidir se lhe dará um nome humano ou animal. Com a dúvida persistindo, decide dar-lhe o nome do dia da semana em que fora salvo, pelo calendário de Robinson: Sexta-feira.

Sexta-feira passa por um longo processo de adestramento com Robinson, que acredita que ele não pensa, porque não fala a língua de Robinson. Para Robinson, ele seria uma criatura "bestial".

Certas vezes Sexta-feira permanecia longo tempo desaparecido e Robinson acaba por descobrir seu esconderijo: um lugar no qual ele plantara arbustos de cabeça para baixo, colocara uma rede, máscaras de madeira, cadáveres ressecados de aves etc. - indícios de um universo secreto do qual Robinson não tinha a chave.

Tournier narra ainda uma situação que evidencia como a relação com o outro envolve também um confronto de sensibilidades. Ocorre quando Sexta-feira passa a cuidar de um filhote perdido de abutre. Para alimentá-lo mastiga larvas e depois dá para o filhote comer. Sexta-feira explica para Robinson a necessidade dessa alimentação com vermes vivos e frescos, para curar o abutre doente. Robinson foge enojado ao vê-lo nesse trato com o filhote.

Mas a devoção e lógica impávida do companheiro impressionaramno. Pela primeira vez, Robinson perguntou-se se as suas exigências de delicadeza, as suas repugnâncias, as suas náuseas, todo esse nervosismo de homem branco não seriam um último e precioso testemunho de civilização ou, pelo contrário, um balastro morto, que seria necessário um dia rejeitar para entrar numa vida nova (TOURNIER, 2001, p. 153).

Robinson mantinha uma reserva de pólvora escondida em uma caverna. Certo dia Sexta-feira - que costumava fumar escondido, utilizando a reserva de tabaco de Robinson (Robinson tinha reservas de tudo!) fumava próximo à caverna e, ao perceber que Robinson se aproxima, joga 
o cigarro, para não ser descoberto. Isto provoca uma explosão acidental que destrói todo o trabalho de Robinson, tudo o que ele construíra na ilha.

Mas apenas então, depois de eliminados todos os rastros da antiga civilização que Robinson lutava por manter, é que ele começa a ver Sextafeira como alguém com modos de sentir, pensar, agir, relacionados a outra cultura, a outras formas de vida. Passa a aprender com ele. E com a ilha. Uma aprendizagem que se dá por contágio, contaminação.

E então a relação entre eles vai ganhando outros contornos e lógicas. Não mais aquela de senhor-escravo e sim uma relação mais fraterna. Sexta-feira passando a dar o tom da relação que se torna cada vez mais lúdica. Robinson é atravessado por uma série de metamorfoses: seu rosto transforma-se, seu corpo vai aprendendo no contato com Sexta-feira e com a ilha. Corpo de Speranza - assim nomeou a ilha - afetando e sendo afetado por ele. Aprende a desenvolver a ambivalência dos membros e inúmeros exercícios e jogos corporais. Aprende a utilizar arco e flecha. Nesse processo, é como se sua estabilidade agora se construísse na relação com a ilha, com seu corpo e não mais da repetição de antigos hábitos e rotinas.

Robinson vai se tornando solar.

Quando finalmente chega um navio europeu na ilha, Robinson fica aterrorizado com as atitudes dos seus tripulantes no contato com a ilha. Ele não se reconhece como alguém que compartilha desse modo de ser e apreender o mundo dos europeus que desembarcam e pilham a ilha como se fosse um brinquedo seu. Robinson se esconde e quem vai embora com eles para a Europa é Sexta-feira.

Ao falar do livro de Tournier, Deleuze retoma uma ideia presente em um de seus primeiros textos, Causas e razões das ilhas desertas, mantido inédito até ser publicado, em 2002, na antologia $A$ Ilha deserta $e$ outros textos. O texto começava por uma distinção entre dois tipos de ilha, distinção geográfica, ou seja, vinda de um discurso científico. Tal distinção era aproximada dos poderes ou características que as ilhas desertas têm para o nosso imaginário, numa tentativa de tornar "a mitologia mais material" e "a ciência, mais animada" (DELEUZE, 2006b, p. 17). A 
geografia define, assim, dois tipos de ilha: as continentais, que são ilhas apenas por derivação, constituídas de porções de terra que se separam do continente, e as oceânicas, formadas de corais e de erupções do fundo do mar e, como tais, ilhas originárias, sem relação com o continente em sua formação. Para Deleuze, esses dois tipos de ilha exprimem, cada uma a seu modo, um combate entre o oceano e a terra. As ilhas continentais nos lembram que o mar circunda a terra, podendo avançar sobre ela na primeira oportunidade. Já as ilhas oceânicas nos mostram que sob o mar também há terra, esperando ter forças suficientes para irromper à superfície. Esse combate entre os elementos, de que as ilhas nos dão testemunho, torna "filosoficamente normal", como diz Deleuze, que elas sejam desertas. O homem não é bem-vindo nesse campo de batalha entre céu e mar, entre mar e terra. As ilhas só se tornam habitáveis porque fazemos de conta que esse combate não existe.

Mas qual seria então a relação entre o ponto de vista mitológico e o geográfico a respeito das ilhas? Deleuze nos diz que "o impulso do homem que o arrasta em direção às ilhas retoma o duplo movimento que produz as ilhas nelas mesmas". O que nos atrai às ilhas é tanto um anseio por isolamento (notemos de passagem a raiz comum entre essas palavras), quanto uma vontade de recomeçar. Não apenas há ilhas derivadas, mas as ilhas são "aquilo em direção a que derivamos". Às ilhas originárias corresponde uma imagem da ilha como "origem radical e absoluta" (DELEUZE, 2006b, p. 18), ilha na qual gostaríamos de recomeçar uma nova vida, talvez uma nova civilização. $\mathrm{O}$ homem que se dirige a uma ilha assume os movimentos que engendram a própria ilha, o que implica que, rigorosamente falando, toda ilha seja deserta. Se os homens que passam a povoar uma ilha levassem às últimas consequências o isolamento, a separação do resto do mundo e a recriação de um novo mundo sobre a ilha, "eles apenas dariam à ilha uma imagem dinâmica dela mesma" (DELEUZE, 2006b, p. 18). Os homens sobre a ilha constituiriam para ela a "consciência do movimento que a produziu" (DELEUZE, 2006b, p. 19), mas que a produziu como ilha deserta. Assim se engendraria uma imagem imaginária entre a ilha e seus habitantes, unidade em que a ilha é "tão-somente o sonho do homem, e o homem seria a pura consciência da ilha" (DELEUZE, 2006b, p. 19). Esses termos colocados por Deleuze 
já apontam para a ilha como lugar privilegiado para a experimentação em torno da ausência de outrem, já que a imagem da ilha implica numa absorção do homem na batalha travada entre os elementos. O homem se torna ele também elementar ao se relacionar com a ilha, e não com outros possíveis habitantes. Lembremos apenas que a dissolução de outrem não implica em eliminação da diferença ou da alteridade. Um mundo sem outrem é um mundo de subjetivações não identitárias, um mundo em que o outro, ou, melhor ainda, as diferenças, não podem ser acomodadas à identidade de um outro eu posto em face de minha identidade.

Essa ideia de um combate entre os elementos será retomada na leitura do livro de Tournier, mas desloca-se para uma luta travada entre céu e terra, e não mais entre terra e mar. Entretanto, as forças celestiais e telúricas constituirão não apenas elementos, mas "figuras completas e opostas, cada qual reunindo, por conta própria, os quatro elementos" (DELEUZE, 1998, p. 312). A terra configura aquilo que mantém cada elemento em seus próprios limites, nas profundezas dos corpos, ao passo que o céu é o que faz explodir esses contornos, liberando uma energia cósmica una a partir dos quatro elementos. Mas tal unidade ainda permite que cada elemento conserve suas propriedades, mas agora em superfície. Essa aventura dos elementos concerne não apenas Robinson, mas também Sexta-feira e a ilha, fazendo de todos eles os heróis do romance, segundo séries ressoantes, mas diferentes.

Na série de Robinson acompanhamos sua progressiva perversão. O Robinson de Tournier não é mais assexuado como o de Defoe, mas sua sexualidade vai se tornando perversa, na medida em que seu desejo é introduzido num outro sistema, a partir de um desvio com relação aos fins e alvos. Não é apenas que sua sexualidade não vise mais a reprodução, ela não visa nem mesmo um outro ser humano, tornando-se cósmica ao esposar os elementos. A perversão de Robinson acompanha-se de um processo de perda da categoria outrem. O próprio encontro com Sextafeira já não se dá mais nesses termos, pois Robinson já não dispõe mais dessa possibilidade. Através da narrativa desta experimentação num mundo sem outrem, podemos, de maneira indutiva, chegar a conclusões sobre a natureza de outrem. Verificando os efeitos da ausência de outrem, induziremos os efeitos de sua presença no mundo povoado por ele. 
Um primeiro efeito de outrem diz respeito à percepção dos objetos no espaço. Outrem define as margens que contornam o objeto percebido por mim, como um fundo do qual podem surgir outros objetos. Os objetos que não vejo ou as partes de um objeto que percebo, mas que não vejo no momento presente, são definidos como visíveis por outrem. É o fato de os objetos que não vejo serem vistos por outrem que suaviza seu surgimento em meu campo perceptivo. Outrem funciona como regulador "das transformações da forma e do fundo", relativizando "o não-sabido, o não-percebido" ao introduzir "o signo do não percebido no que eu percebo, determinando-me a apreender o que não percebo como perceptível para outrem". Na ausência de outrem, não há mais suavidade nas transições, há apenas uma oposição absoluta entre luz e obscuridade, entre "o sabido e o não-sabido", entre "o percebido e o não-percebido" (DELEUZE, 1998, p. 315). Com o desaparecimento de outrem, também se esvai a categoria do possível, não há mais horizonte de onde o possível venha a surgir. Desse primeiro grupo de efeitos de outrem, deduzimos que outrem não é nem um objeto em meu campo perceptivo, nem um sujeito que me percebe. Outrem é uma estrutura que condiciona o funcionamento de minha percepção, estrutura que pode ser em seguida preenchida por outros indivíduos particulares, mas que não se confunde com eles, é anterior a eles.

A estrutura que outrem confere a minha percepção é justamente a estrutura do possível. Outrem exprime um mundo possível que tem uma realidade determinada, não é apenas uma abstração. É preciso considerar, no entanto, que o mundo exprimido por outrem não existe independentemente fora da sua expressão. Não há uma relação de semelhança entre o exprimido e sua expressão, mas uma relação de envolvimento, de implicação ou complicação. No exemplo de Deleuze, "um semblante assustado é a expressão de um possível mundo assustador ou de alguma coisa de assustador no mundo que ainda não vejo" (DELEUZE, 1998, p. 317). Enquanto não vejo o tal mundo assustador, sua existência permanece, para mim, atrelada ao semblante assustado que o exprime como possibilidade. Mas o semblante amedrontado e o que causa medo não se assemelham, apenas um envolve o outro, implica o outro. Quando busco perceber o que causa medo em outrem, desdobro ou explico o mundo envolvido na expressão de outrem, realiza-se o mundo possível aberto por outrem. 
Nesse ponto, Deleuze recorre brevemente a Proust, movimento que retoma tantas vezes em sua obra. No amor proustiano, o ciúme dá testemunho justamente do pressentimento desses mundos possíveis envolvidos por outrem, mundos em que o amante não é mais (ou não é ainda) o preferido de sua amada. Por isso, o ciúme deflagra uma verdadeira investigação, como busca de explicar tais mundos possíveis, conferir-lhes uma realidade independente.

A possibilidade de outros mundos trazida por outrem é que sustenta a distinção entre minha consciência e os objetos percebidos por ela. Antes do aparecimento de outrem, minha consciência está como que colada ao objeto, inadvertida em relação às partes desconhecidas e despercebidas dele e em relação a outros objetos, outros mundos possíveis. Com o surgimento surpreendente de outrem, rompe-se a harmonia entre minha consciência e o objeto. Outrem me faz vislumbrar mundos possíveis assustadores, porque eu não os tinha previsto, e a afirmação da existência desses mundos joga para o passado o mundo em que eu percebia o objeto. Assim, a distinção entre a consciência e o objeto é uma distinção temporal. Nas palavras de Tournier:

De repente se produz um desligamento. O sujeito se arranca do objeto, despojando-o de uma parte de sua cor e de seu peso. Alguma coisa arrebentou no mundo e todo um conjunto de coisas se desmorona convertendo-se em mim. Cada objeto é desqualificado em proveito de um sujeito correspondente. A luz se torna olho e não existe mais como tal: ela não é mais do que excitação da retina. O odor torna-se narina - e o próprio mundo se revela inodoro. A música do vento nas árvores é refutada: não era mais do que um abalo de tímpano... O sujeito é um objeto desqualificado. Meu olho é o cadáver da luz, da cor. Meu nariz é tudo o que resta dos odores quando sua irrealidade foi demonstrada. Minha mão refuta a coisa que segura. O problema do conhecimento nasce, então, de um anacronismo. Ele implica a simultaneidade do sujeito e do objeto, cujas misteriosas relações gostaria de esclarecer. Ora, o sujeito e o objeto não podem coexistir, uma vez que são a mesma coisa, primeiro integrada ao mundo real, depois jogada fora como rebotalho (TOURNIER, 1967, p. 82-84 apud DELEUZE, 1998, p. 320.) 
Quando outrem desaparece, não apenas o outro empírico, mas outrem como estrutura a priori da percepção, a consciência e os objetos são devolvidos a uma indistinção. A consciência não é mais uma luz que se dirige para as coisas, mas é um brilho das coisas mesmas, uma espécie de fosforescência dos objetos. Nessas condições, a consciência de Robinson se confunde com as coisas que o cercam. Ora, o que o cerca é precisamente a ilha. Assim, Robinson se torna a consciência da ilha. Deleuze retoma aqui o texto de que falávamos acima, Causas e razões das ilhas desertas, lapidando sua formulação acerca do paradoxo que envolve a ilha deserta. Tal paradoxo implica que a ilha permaneça deserta a despeito de passar a ser habitada por um náufrago, com a condição de que este náufrago perca a estrutura outrem. O náufrago, então, não se torna um habitante da ilha que viria a romper seu caráter de deserta, mas confunde-se com a ilha, tornando-se sua consciência.

O mundo estruturado por outrem era constituído por objetos como que recurvados uns sobre os outros, na medida em que eram compostos de miragens que possibilitavam a transição de um para o outro. Na ausência de outrem, explodem as formas, os elementos desprendem-se dos corpos, de cada coisa, emerge um duplo constituído pela consciência tornada luz fosforescente do objeto. Deleuze retoma aqui a topologia que desenvolve ao longo de Lógica do sentido, com uma patologia correspondente. Com a perda de outrem, Robinson vive um processo que passa pela neurose e pela psicose para culminar numa perversão que exprime, na verdade, sua grande Saúde. Os momentos neurótico e psicótico estão ligados à profundidade, à dimensão em que os corpos se interpenetram, se fundem e se atacam mutuamente. A neurose é o momento em que não existem outros indivíduos para preencher a estrutura outrem, mas a estrutura ela mesma ainda subsiste. Robinson mobiliza todos os seus esforços para tentar manter a organização que era antes assegurada por outrem. Robinson procura medir a passagem do tempo, produzir víveres para seu sustento de maneira ordenada e assim por diante. Mas a estrutura começa a ruir, o que leva Robinson a um "duplo frenesi” (DELEUZE, 1998, p. 324): o de uma produção desenfreada de um excedente inconsumível, aliado ao despertar de uma sexualidade por assim dizer involutiva, que desposa a Terra, como atesta o episódio em que Robinson encontra uma gruta e, nela, 
uma concavidade na qual aninha todo o seu corpo. Outrem organizava uma superfície em que as coisas se delimitavam em formas definidas, em que a linguagem era tornada possível, o sentido ideal desprendia-se da profundidade corporal das coisas. Com o desmoronamento da estrutura outrem, perde-se a superfície, não há mais sentido possível, os próprios corpos se tornam simulacros ou vestígios.

A única saída para Robinson é reinstaurar a superfície, uma superfície celeste e solar. Quem possibilita essa metamorfose final é Sextafeira. De fato, como diz Deleuze, Sexta-feira "destrói a ordem econômica e moral instaurada por Robinson na ilha” (DELEUZE, 1998, p. 325), dando um golpe final nos vestígios da estrutura outrem. Sexta-feira provoca também a catástrofe que devolve a ilha a seu caráter elementar, fazendo-a explodir ao fumar o tabaco que não deveria ser consumido ao lado do local onde estava armazenada a pólvora. Sexta-feira sacrifica um bode que o havia ferido, como num rito iniciático para Robinson, fazendo o bode voar e cantar, ao transformá-lo em pipa e instrumento musical eólico. Mas a participação de Sexta-feira mais essencial, nos diz Deleuze, é apresentar "a Robinson a imagem do duplo pessoal, como complemento necessário da imagem da ilha" (DELEUZE, 1998, p. 325). Por esse viés, Sexta-feira revela para Robinson os elementos livres, por trás das imagens ou duplos formados por eles. Mas Sexta-feira só desempenha esse papel porque não funciona mais como outrem para Robinson, nem mesmo no que diz respeito à sexualidade.

Sexta-feira funciona como um oposto de outrem. Como diz Deleuze, "Outrem baixa: baixa os elementos na terra, a terra em corpos, os corpos em objetos". Sexta-feira faz exatamente o movimento contrário, erguendo ou endireitando "os objetos e os corpos", levando "a terra até o céu", liberando "os elementos". Havíamos dito que o mundo sem outrem de Robinson era um desvio em relação ao nosso mundo habitual. Mas, do ponto de vista desse novo mundo das superfícies puras, dos elementos liberados, outrem é que era um desvio que baixava "meus desejos sobre os objetos, meus amores sobre os mundos". É nesse desvio por outrem que a sexualidade se faz reprodução a partir da diferenciação dos sexos. Sem outrem, não há mais diferenciação sexual, mas uma sexualidade que se conecta com os elementos tornados celestiais, solares ou aéreos, assim como não há mais percurso do desejo a um objeto. O desejo é referido 
diretamente "a uma causa pura: os Elementos". Mas se esta eliminação do desvio nos parece uma perversão, é justamente porque ela só foi obtida às custas da eliminação de outrem. Aí está o sentido das aventuras de Robinson e de todo o romance de Tournier. Nas palavras de Deleuze,

Tournier supõe que através de muitos sofrimentos Robinson descobre e conquista uma grande Saúde, na medida em que as coisas acabam por se organizar bem diferentemente do que o fariam com outrem presente, porque liberam uma imagem sem semelhança, um duplo delas próprias ordinariamente recalcado e que este duplo, por sua vez, libera puros elementos ordinariamente prisioneiros (DELEUZE, 1998, p. 326-328).

Assim, a ausência de outrem deixa de ser uma perturbação do mundo. Ao contrário, Robinson passa a considerar que a presença de outrem é que era perturbadora, na medida em que escondia "o duplo glorioso do mundo". Outrem era abertura de mundos possíveis, mas sua ausência abre uma outra possibilidade: a "descoberta da superfície, do além elementar, do Outro para Outrem” (DELEUZE, 1998, p. 326-328).

$* * *$

Realizado nosso percurso pelos textos deleuzianos, como conjugar com eles o verbo aprender? Ao longo desse artigo, fomos apontando alguns aspectos relativos à aprendizagem. Aprender envolve um processo sobre o qual não se tem controle, tornando-se uma aventura imprevisível, deflagrada pelo contato com diferenças desestabilizadoras de certezas, provocando problemas novos.

Pode até haver métodos para ensinar (eles pelo menos servem para tranquilizar as consciências perturbadas dos professores), mas não há métodos para aprender. O método é uma máquina de controle, mas a aprendizagem está para além de qualquer controle; a aprendizagem escapa, sempre. $\mathrm{O}$ aprendizado não pode ser circunscrito nos limites

1 As citações anteriores encontram-se também nestas páginas. 
de uma aula, da audição de uma conferência, na leitura de um livro; ele ultrapassa todas essas fronteiras, rasga os mapas e pode instaurar múltiplas possibilidades (GALLO, 2003, p. 104).

Se os espaços e tempos da aprendizagem são ilimitados, abertos, pode-se afirmar que ela também não é mensurável. Torna-se singular e singularizante.

A diferença é decisiva no aprendizado. Pudemos acompanhar, nas relações entre Robinson, Speranza e Sexta-feira, os embates em torno dos processos de liberação de múltiplos devires. Essas metamorfoses envolvem certas lutas entre caos e pensamento. Apenas quando Sexta-feira acidentalmente explode a ilha civilizada de Robinson acontece de este último ser levado a desfazer-se dos territórios existenciais já conhecidos, abrindo-se à possibilidade de criação de outras formas de vida. Mesmo que tenhamos acompanhado a perda progressiva da estrutura Outrem, será a explosão que incitará a radicalidade das metamorfoses que atravessam Robinson, com a constituição de um mundo de subjetivações não identitárias e a crescente contaminação pelos elementos da ilha. Deslocamento provocado pela variabilidade caótica, no qual as metamorfoses ganham velocidade, potência, radicalidade. Vimos o quanto Robinson procurou evitar essa variabilidade, apegando-se aos seus antigos hábitos e costumes, buscando reproduzir na ilha seu modo de existência europeu.

Nessa luta contra a variabilidade, vemos emergir uma relação com a alteridade que escapa das armadilhas dos modelos e moldes. $\mathrm{O}$ apego a modelos parece responder à tentativa de manter a estabilidade. Ao pensar com Deleuze a experiência do aprendizado, Luiz Orlandi afirma que um dos perigos do ensino é "aquele que consiste em evitar o confronto com a variabilidade caótica através da acomodação do corpo e/ou do espírito a modelos de vida, a modelos de conduta, a modelos conceituais, a modelos científicos, a modelos estéticos e assim por diante" (ORLANDI, 2011, p. 150). Os combates entre caos e pensamento são permanentes. O caos "é o inimigo aliado do pensar que o enfrenta. Por quê? Porque os encontros intensivos entre ambos é que restauram a possibilidade de criação, a possibilidade do novo (....)" (ORLANDI, 2011, p. 150).

Aprender envolve uma abertura para a alteridade, algo que nos toma, nos arranca dos territórios costumeiros. Não basta nossa boa vontade, 
mas implica em um agenciamento desejante. No aprendizado "a busca é desencadeada por algo que intensifica a sensibilidade e força todas as outras faculdades a irem além de sua inércia habitual ou da acumulação de um saber abstrato" (ORLANDI, 2011, p. 148). Tese já presente em Proust e os signos, pois ali "'aprender diz respeito essencialmente aos signos" (DELEUZE, 1987, p. 10), signos com que nos deparamos em certos encontros e que nos coagem a pensar" (ORLANDI, 2011, p. 148). Aprender implica o encontro intensivo com os signos. Encontro que transborda estruturas organizadas do ensino e ultrapassa a ideia de se tomar o outro como modelo. O signo implica a heterogeneidade como relação. Não se aprende fazendo como o outro, mas fazendo com. Será após o surgimento de Sexta-feira que Robinson rirá pela primeira depois do naufrágio. "Seria o primeiro efeito da presença de um companheiro? A faculdade de rir terlhe-ia sido dada ao mesmo tempo que uma sociedade, por modesta que fosse?" (TOURNIER, 2001, p. 128). Para ele, Sexta-feira tinha o rosto "desabrochado pelo riso, talhado todo ele para o riso" (TOURNIER, 2001, p. 190). E será Sexta-feira quem o iniciará em novas aprendizagens, após a explosão da ilha administrada. "Debatia-se na sua velha pele um novo Robinson, que aceitava, de antemão, deixar ruir a ilha administrada para se internar, atrás de um iniciador irresponsável, num caminho desconhecido" (TOURNIER, 2001, p. 167). Com ele e Speranza, Robinson foi se tornando outro, solar. As metamorfoses são múltiplas, atravessando seu corpo, a percepção do tempo, desfazendo uma subjetividade moldada pela formahomem, levando-o a modos de subjetivação diferenciais.

Aprender implica em uma exposição, uma experimentação vital, uma abertura para ser afetado pelas diferenças. Para isso, é necessária certa presença e disponibilidade, um estado de alerta. A possibilidade de uma aprendizagem que se faz para além dos modelos, moldes, padrões, na experimentação. Deslocamento em relação ao já sabido, ao já conhecido, possibilitando uma abertura para a criação. Tal processo envolve riscos, pois não se trata de um caminho traçado de antemão.

Aprender é algo que depende do acaso dos encontros, das alianças que as circunstâncias permitem fazer, do impacto que se transmite dos sentidos ao pensamento, provocado por uma diferença sensível, que continua se diferenciando ao passar de uma faculdade a outra (da sensibilidade à memória, à imaginação, ao entendimento como faculdade produtora de conceitos). Nas palavras de Deleuze: 
A partir de que signos da sensibilidade, por meio de que tesouros da memória, sob torções determinadas pelas singularidades de que Idéia será o pensamento suscitado? Nunca se sabe de antemão como alguém vai aprender - que amores tornam alguém bom em Latim, por meio de que encontros se é filósofo, em que dicionários se aprende a pensar (DELEUZE, 2006a, p. 237).

\section{Referências}

DELEUZE, G. Diferença e repetição. 2. ed. rev. e atualizada. Tradução de Luiz Orlandi e Roberto Machado. Rio de Janeiro, Graal, 2006a.

. Causas e razões das ilhas desertas. In: . A ilha deserta. Artigo citado: tradução de Luiz Orlandi. Vários tradutores. São Paulo: Iluminuras, 2006b. p. 17-22.

. Michel Tournier e o mundo sem outrem. In: . Lógica do sentido. Tradução de Luiz Roberto Salinas Fortes. São Paulo: Perspectiva, 1998. p. 311-330.

. Proust e os signos. Tradução de Antonio Piquet e Roberto Machado. Rio de Janeiro: Forense Universitária, 2003.

GALLO, S. Deleuze e a educação. Belo Horizonte: Autêntica, 2003.

ORLANDI, L. B. L. Deleuze- entre caos e pensamento. In: AMORIM, A. C.; GALlO, S.; OLIVEIRA JR., W. M. (Org.). Conexões: Deleuze e imagem e pensamento. Petrópolis: De Petrus; Brasília: CNPq, 2011. p. 145-154.

TOURNIER, M. Vendredi ou les limbes du pacifique. Paris: Gallimard, 1967.

. Sexta-feira ou os limbos do Pacifico. 3. ed. Tradução de Fernanda Botelho. Rio de Janeiro: Bertrand Brasil, 2001.

Data de registro: $30 / 05 / 2013$

Data de aceite: $20 / 11 / 2013$ 